\title{
PERSEPSI MAHASISWA TERHADAP KUALITAS PELAYANAN BIRO ADMINISTRASI UMUM DAN PRODI MANAJEMEN DI UNP KEDIRI
}

\author{
Veny Lailia ${ }^{1}$ \\ Universitas Nusantara PGRI Kediri \\ vennylailia@gmail.com \\ Edy Djoko Soeprajitno² \\ Universitas Nusantara PGRI Kediri \\ edydjoko.s@gmail.com \\ DOI: https://doi.org/10.33592/jeb.v26i1.660
}

\begin{abstract}
The purpose of this study is to analyze student perception of the quality of administrative staff, General Administration Bureau and Management Department at Nusantara PGRI University Kediri. The method used in this study is qualitative. This type of research uses a type of research that refers to descriptive methods. The results of this study are: (1) Students perception of the quality of service in the General Administration Bureau is assessed less well, it is based on a few students statements that the physical facilities are inadequate and lack administrative staff and services provided are less satisfactory because students should queue long. (2) Students perception of the quality of service on the management department is judged quite well, according to some students service process was given by the quite quickly, only the current management department only has one administrative staff.
\end{abstract}

Keywords: Perception, quality of service, students

\begin{abstract}
Abstrak
Tujuan dari penelitian ini adalah untuk menganalisis persepsi mahasiswa terhadap kualitas pelayanan Tenaga Kependidikan Biro Administrasi Umum dan Prodi Manajemen di Universitas Nusantara PGRI Kediri. Metode yang digunakan dalam penelitian ini adalah kualitatif. Jenis penelitian ini Penelitian ini menggunakan jenis penelitian yang mengacu pada metode deskriptif. Hasil penelitian ini adalah: (1) persepsi mahasiswa terhadap kualitas pelayanan pada Biro Administrasi Umum dinilai kurang baik, hal itu didasari pada pernyataan beberapa mahasiswa bahwa fasilitas fisik kurang memadai dan kurangnya tenaga pendidikan dan pelayanan yang diberikan kurang memuaskan sebab mahasiswa harus mengantre lama. (2) persepsi mahasiswa terhadap kualitas pelayanan pada Prodi Manajemen dinilai sudah cukup baik, menurut beberapa mahasiswa proses pelayanan yang diberikan tenaga kependidikan pada Prodi Manajemen lumayan cepat, hanya saja saat ini Prodi Manajemen hanya memiliki 1 tenaga kependidikan.
\end{abstract}

\section{Kata kunci: Persepsi, Kualitas Pelayanan, Mahasiswa}

\section{A. Pendahuluan}

Kesadaran masyarakat yang semakin tinggi akan nilai pendidikan khususnya Perguruan Tinggi mengakibatkan peningkatan tuntutan dari masyarakat terhadap kualitas Perguruan Tinggi, hal ini disebabkan karena Perguruan Tinggi adalah salah satu penyedia layanan atau jasa di bidang pendidikan yang nantinya akan langsung menghasilkan sumber daya manusia yang bermutu dan berkualitas (Kanca, 2015). Kualitas pelayanan merupakan salah satu aspek terpenting yang harus diperhatikan setiap Perguruan Tinggi. Karena, kualitas pelayanan mengukur seberapa bagus tingkat pelayanan yang 
diberikan mampu dan sesuai dengan harapan Mahasiswa pada suatu Perguruan Tinggi (Wibisana, 2017). Menurut Tjiptono (2012), kualitas merupakan suatu kondisi dinamis yang berhubungan dengan produk, jasa, manusia, proses, dan lingkungan yang memenuhi atau melebihi harapan. Sedangkan kualitas pelayanan adalah tingkat keunggulan yang diharapkan konsumen dan pengendalian atas tingkat keunggulan tersebut untuk memenuhi keinginan konsumen.

Menurut Parasuraman (dalam puspitawati, 2017) ukuran kualitas pelayanan adalah bukti langsung, keandalan, daya tanggap, jaminan, dan empati. Kualitas pelayanan dapat menjadi ukuran baik atau buruknya kinerja pelayanan. Semakin baik kualitas pelayanan, semakin baik pula kinerja pegawai pemberi pelayanan (Meilina, 2017). Dapat disimpulkan bahwa kualitas pelayanan adalah penilaian atau persepsi dari pengguna atas keunggulan pelayanan yang diterima sekaligus penilaian atas kinerja pegawai pemberi pelayanan tersebut.

Persepsi Mahasiswa akan penilaian pelayanan pada Perguruan Tinggi merupakan langkah awal dalam meningkatkan kualitas pelayanan. Kualitas pelayanan yang dirasakan oleh Mahasiswa menunjukkan persepsi mereka atas pelayanan yang diberikan. Hal ini menunjukkan bahwa persepsi dan kualitas pelayanan sangat berhubungan langsung kepada penyedia layanan serta Mahasiswa (Niara, Saputra, Sufi, Utami, \& Kuning, 2018). Persepsi merupakan pengalaman tentang objek, peristiwa atau kejadian yang didapatkan dengan menyimpulkan informasi dan menafsirkan pesan (Jalaludin, 2012). Persepsi tidak hanya bergantung pada rangsangan fisik, tapi juga rangsangan yang berhubungan dengan lingkungan sekitar dan keadaan individu yang bersangkutan (Kotler, Phillip, \& Keller, 2016). Syarat-syarat terjadinya persepsi adalah ada sesuatu atau objek yang dipersepsikan, adanya perhatian yang merupakan langkah pertama sebagai suatu persiapan dalam mengadakan persepsi, dan adanya alat indera/reseptor yaitu alat untuk menerima stimulus serta saraf sensoris sebagai alat untuk meneruskan stimulus ke otak, yang kemudian sebagai alat untuk mengadakan respon (Sunaryo, 2011). Penyedia layanan pada Perguruan Tinggi saat ini semakin hari semakin bersaing dalam meningkatkan pelayanan yang diberikan kepada Mahasiswa. Seperti fenomena yang terjadi pada saat ini, banyaknya Perguruan Tinggi khususnya di Kota Kediri yang bersaing tidak hanya mutu namun juga meningkatkan fasilitas-fasilitas yang ada di Perguruan Tinggi. Salah satunya adalah Universitas Nusantara PGRI Kediri (UNP Kediri).

UNP Kediri merupakan salah satu Perguruan Tinggi yang ada di Kota Kediri. Terdapat cukup banyak Perguruan Tinggi seperti Sekolah Tinggi Agama Islam Negeri Kediri (IAIN Kediri), Universitas Pawyatan Daha Kediri, STIE Wahidiyah Kediri, STMIK Cahaya Surya Kediri, STMIK Kadiri, Politeknik LP3I, Akademi Keperawatan Dharma Husada Kediri, Akademi Manajemen Koperasi Kediri, Universitas Islam Kadiri (UNISKA), Universitas Kadiri (UNIK), Universitas Kahuripan Kediri, dan Sekolah Tinggi Agama Islam Badrus Sholeh Purwoasri Kediri. Agar dapat bersaing dengan Perguruan Tinggi tersebut, maka UNP Kediri harus memiliki keunggulan pada kualitas pelayanannya. Karena sebuah pelayanan akan menentukan bagaimana kualitas dari Perguruan Tinggi tersebut. Apabila pelayanan yang diberikan menurut mahasiswa itu baik, maka sebuah Perguruan Tinggi tersebut bisa dikatakan baik. Namun, 
sebaliknya jika pelayanan yang dimiliki suatu Perguruan Tinggi buruk, maka Perguruan Tinggi tersebut akan dikatakan buruk dalam hal pelayanan (Rahayu, Lubis, \& Lubis, 2017).

Pelayanan pada UNP Kediri dilakukan oleh Tenaga Kependidikan (Tendik) yang sebagian besar tertuju pada 2 aspek, yaitu untuk pembayaran melalui Biro Administrasi Umum (BAU) dan untuk administrasi terkait kelancaran perkuliahan oleh Tenaga administrasi melalui Program Studi (Prodi). BAU dan Prodi berkewajiban dalam memberikan pelayanan yang maksimal, mengingat perannya yang mengelola kemahasiswaan dan kelancaran administratif perkuliahan, maka pelayanan yang diberikan berhubungan langsung pada Mahasiswa.

Salah satu unit yang ada di UNP Kediri adalah Prodi Manajemen. Prodi Manajemen merupakan salah satu Prodi yang ada di Fakultas Ekonomi Universitas Nusantara PGRI Kediri dengan jumlah Mahasiswa paling banyak daripada Prodi lain, sehingga jika ada kekurangan pada kualitas pelayanannya, dan mereka menyuarakan keluhan pada pihak luar, maka akan merusak citra UNP Kediri. Maka dari itu baik BAU maupun Prodi harus memberikan pelayanan yang berkualitas kepada Mahasiswa. Karena, kualitas pelayanan ini merupakan salah satu bagian dari strategi manajemen yang akan berdampak langsung pada citra UNP Kediri.

Dari sisi pelayanan, selama ini validasi pembayaran Mahasiswa setiap semester harus mengurus di BAU. Beberapa Mahasiswa merasa cukup puas terhadap pelayanan yang diberikan BAU. Namun, tidak jarang ada beberapa Mahasiswa yang mengeluh terkait pelayanan di BAU. Adapun diantaranya keluhan tersebut mengenai pelayanan BAU yang dirasa kurang efektif sehingga mengakibatkan
Mahasiswa harus menunggu lama dalam proses administrasi. Selain itu, jumlah petugas yang minim turut berpengaruh dalam lamanya proses pelayanan.

Adapun dari sisi pelayanan Prodi Manajemen, sebagian Mahasiswa merasa cukup puas atas pelayanan yang diberikan oleh Prodi dikarenakan mereka jarang menggunakan jasa Prodi. Sebaliknya, ada beberapa Mahasiswa yang memiliki keluhan terkait pelayanan pada Prodi Manajemen, seperti Tenaga administrasi yang kurang cepat tanggap dalam melayani kebutuhan Mahasiswa, kurang disiplin dalam hal ketepatan waktu, dan tidak jarang Mahasiswa mengeluhkan mengenai terbatasnya informasi yang mereka dapat dari Prodi terkait dengan kepentingan perkuliahan. Namun, tidak setiap Mahasiwa memiliki keluhan yang sama. Dari pelayanan yang telah diberikan oleh BAU dan Prodi, ternyata dapat menimbulkan persepsi yang berbeda-beda bagi mahasiswa.

Mengacu pada beberapa uraian di atas, dalam hal ini penulis meneliti tentang "Persepsi Mahasiswa Terhadap Kualitas Pelayanan Tenaga Kependidikan BAU Dan Prodi Manajemen Di UNP Kediri”. Dengan diketahuinya persepsi Mahasiswa tentang kualitas pelayanan tersebut akan menentukan apakah pelayanan yang diberikan telah memenuhi kebutuhan dan harapan Mahasiswa.

\section{B. Metode Penelitian}

Adapun dalam penelitian ini menggunakan pendekatan penelitian kualitatif. Penelitian kualitatif merupakan penelitian yang bertujuan untuk memahami mengenai fenomena yang dialami subjek peneliti secara menyeluruh dan mempertimbangkan segala aspek yang mempengaruhi dengan 
cara mendeskripsikan hasil penelitian dalam bentuk kata-kata dan bahasa pada suatu konteks yang alamiah dengan memanfaatkan berbagai metode alamiah (Moleong, 2017). Lokasi penelitian adalah UNP Kediri, subjek penelitian adalah Mahasiswa Prodi Manajemen yang pernah melakukan proses pelayanan pada BAU dan Prodi Manajemen di UNP Kediri. Pendekatan kualitatif ini dipilih agar dapat mengetahui pandangan atau persepsi dari setiap mahasiswa secara mendalam ketika menghadapi proses pelayanan. Informan dalam penelitian ini dipilih yang memenuhi kriteria: Relevance (peneliti memastikan informan yang mengerti masalah yang diteliti), Recommendation (peneliti memilih informan berdasarkan rekomendasi dari kaprodi manajemen yaitu mahasiswa yang sering melakukan proses pelayanan di BAU maupun Prodi Manajemen), Readiness (peneliti melakukan wawancara pada saat informan menyatakan siap untuk diwawancarai), Reassurance (informan menyatakan bersedia memberikan jawaban jujur, jelas, dan terbuka tanpa tekanan dari pihak manapun). Peneliti memutuskan untuk melakukan wawancara pada 5 Mahasiswa Prodi Manajemen.
Teknik pengumpulan data dilakukan dengan wawancara pada informan untuk mengetahui kualitas pelayanan yang dilakukan Prodi Manajemen dan BAU UNP Kediri. Teknik pengambilan data dalam penelitian ini menggunakan sumber data primer yang diambil dari hasil wawancara baik langsung dan tidak langsung menggunakan aplikasi WhatsApp. Wawancara langsung menggunakan perekam handphone dan melakukan pencatatan langsung, sedangkan wawancara tidak langsung menggunakan fitur voice note maupun tertulis. Selain itu untuk menguji kredibilitas data tersebut peneliti menggunakan triangulasi teknik dan dilakukan dengan cara membandingkan informasi atau data yang diperoleh dari narasumber dengan cara yang berbeda. Dalam penelitian ini peneliti menggunakan metode wawancara, observasi, serta dokumentasi.

Fokus dan tujuan dalam penelitian ini menggunakan standar-standar pengukuran kualitas pelayanan, antara lain bukti langsung, keandalan, daya tanggap, jaminan, serta empati. Pertanyaan yang digunakan untuk menggali informasi adalah sebagai berikut:

1. Pertanyaan mengenai Bukti langsung dari BAU dan Prodi Manajemen: 
a. Bagaimana pendapatmu mengenai fasilitas fisik, perlengkapan jumlah tendik, dan saranan komunikasi di BAU dan Prodi Manajemen saat ini?

2. Pertanyaan mengenai Keandalan dari BAU dan Prodi Manajemen:

a. Bagaimana pendapatmu mengenai kemampuan tendik dalam memberikan pelayanan?

b. Apakah pelayanan yang tendik berikan sudah sesuai dan memuaskan?

3. Pertanyaan mengenai Daya tanggap dari BAU dan Prodi Manajemen:

a. Bagaimana pendapatmu mengenai daya tanggap atau respon tendik BAU dan Prodi Manajemen dalam memberikan pelayanan?

4. Pertanyaan mengenai Jaminan dari BAU dan Prodi Manajemen:

a. Bagaimana pendapatmu mengenai kemampuan tendik BAU dan Prodi Manajemen dalam memberikan kepercayaan atau kepastian mengenai informasi yang diperlukan Mahasiswa?

5. Pertanyaan mengenai Empati dari BAU dan Prodi Manajemen: a. Bagaimana pendapatmu mengenai kemampuan tendik dalam menjalin komunikasi dengan Mahasiswa?

Analisis data dilakukan dengan beberapa tahapan seperti reduksi data (mengambil data yang penting dan sesuai, serta membuang data yang dianggap tidak perlu), tahapan penyajian data (menyajikan data dan mengorganisir data yang sudah direduksi sehingga tampak hubungan dan keterkaitannya), dan tahapan penarikan kesimpulan. Secara diagram tahapan dalam penelitian ini adalah sebagai berikut:

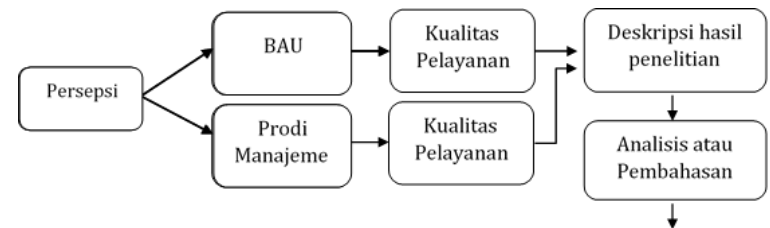

Gambar 1. Diagram penelitian

Penelitian ini dilakukan untuk mengetahui persepsi Mahasiswa terhadap kualitas pelayanan yang diberikan BAU dan Prodi Manajemen UNP Kediri.

\section{Hasil Penelitian dan Pembahasan}

Tabel 1

Hasil Wawancara tentang Bukti Langsung

\begin{tabular}{|l|l|}
\hline Informan & \multicolumn{1}{|c|}{ Hasil wawancara } \\
\hline & $\begin{array}{l}\text { Pertanyaan pertama: } \\
\text { Bagaimana pendapatmu } \\
\text { mengenai fasilitas fisik, } \\
\text { perlengkapan, jumlah tendik, dan } \\
\text { sarana komunikasi di BAU dan } \\
\text { Prodi Manajemen saat ini. }\end{array}$ \\
\hline & Jawaban: \\
\hline
\end{tabular}




\begin{tabular}{|c|c|}
\hline $\mathbf{N}$ & $\begin{array}{l}\text { BAU: } \\
\text { Kalau menurut saya, fasilitas } \\
\text { fisiknya kurang, soalnya kan } \\
\text { kurang ada tempat tunggunya ya } \\
\text { biasanya kan tutup, harus nunggu } \\
\text { sampai bukanya lah itu kurang } \\
\text { gitu. Kadang kan antre gitu uwel- } \\
\text { uwelan ya. Kalau petugasnya } \\
\text { saya rasa juga kurang kadang kan } \\
\text { hanya ada } 1 \text { kadang kan } 2 \text {. } \\
\text { Cuman dari sekian banyak } \\
\text { mahasiswa kan menurut saya kan } \\
\text { kurang gitu harus tambah lagi. } \\
\text { Prodi: Kalau fasilitasnya cukup baik } \\
\text { dari Prodi, kalau menurut saya } \\
\text { kalau tendiknya kurang ya } \\
\text { adminnya cuma } 1 \text { sedangkan } \\
\text { mahasiswanya juga segitu } \\
\text { banyaknya, jadi kan kalau ada } \\
\text { apa-apa antre dulu atau kurang } \\
\text { lah. }\end{array}$ \\
\hline $\mathbf{A}$ & $\begin{array}{l}\text { BAU: } \\
\text { Sudah cukup baik, namun masih } \\
\text { ada yang kurang yaitu tempat } \\
\text { untuk menunggu antriannya } \\
\text { kurang nyaman sehingga pada } \\
\text { saat mahasiswa akan melakukan } \\
\text { validasi pembayaran harus } \\
\text { berdiri menunggu giliran. } \\
\text { Prodi: } \\
\text { Menurut saya kurang baik, } \\
\text { karena Prodi hanya memiliki } 1 \\
\text { tenaga adiministrasi sehingga } \\
\text { tidak bisa memahami keperluan } \\
\text { mahasiswa secara maksimal. }\end{array}$ \\
\hline IZ & $\begin{array}{l}\text { BAU: } \\
\text { Itu fisik e ya lumayan tapi bagi } \\
\text { para mahasiswa yang mau minta } \\
\text { tentang apa itu antrinya lama } \\
\text { banget terus tenaga kerjanya } \\
\text { kurang. Perlengkapannya itu } \\
\text { lumayan, ya lumayan komplit. } \\
\text { Jumlahnya kira-kira berapa ya, } \\
\text { yaa kalau melayani itu gimana } \\
\text { ya, sedikit lama lah. Sarana } \\
\text { komunikasine yo baik tidak } \\
\text { terlalu ramahlah ya sopan. } \\
\text { Prodi: } \\
\text { Lek fasilitas fisik e tuh sempit } \\
\text { lah terus perlengkapan e sudah } \\
\text { ada terus jumlah tenaga kerjanya } \\
\text { tuh kurang hanya Pak Andi aja, } \\
\text { kan? Lah mahasiswa itukan mau }\end{array}$ \\
\hline
\end{tabular}

\begin{tabular}{|c|c|}
\hline & $\begin{array}{l}\text { minta tanda tangan atau apa } \\
\text { keperluan apa itu Pak Andi } \\
\text { nggak ada tuh susah carinya. }\end{array}$ \\
\hline $\mathbf{E}$ & $\begin{array}{l}\text { BAU: } \\
\text { Kalau menurut saya sih sudah } \\
\text { cukup baik di BAU, namun } \\
\text { masih ada beberapa yang kurang } \\
\text { untuk tempat menunggu antrian } \\
\text { itu kalau menurut saya kurang } \\
\text { nyaman. Jadi, waktu mahasiswa } \\
\text { melakukan validasi pembayaran } \\
\text { terkadang tuh harus menunggu } \\
\text { giliran, jadi sampai berkerumun } \\
\text { berdiri, jadi menurut saya itu } \\
\text { tempat duduknya yang kurang. } \\
\text { Prodi: } \\
\text { Kalau di Prodi menurut saya sih } \\
\text { sudah cukup baik, ya. Kalau } \\
\text { fasilitas tunggu di luar Prodi itu } \\
\text { menurut saya sudah cukup } \\
\text { nyaman soalnya kan disediakan } \\
\text { bangku-bangku hampir itu } 1 \\
\text { lorong kan banyak bangku- } \\
\text { bangku, jadi bisa untuk tempat } \\
\text { menunggu. Tetapi, kalau di } \\
\text { dalamnya itu kalau menurut saya } \\
\text { masih kurang soalnya tempat... } \\
\text { tempat tunggu yang disediakan } \\
\text { tuh cuman kecil gitu aja... sudah } \\
\text { itu. }\end{array}$ \\
\hline $\mathbf{R}$ & $\begin{array}{l}\text { BAU: } \\
\text { Fasilitas fisik, perlengkapan, } \\
\text { jumlah tendik dan sarana } \\
\text { komunikasi. Di BAU fasilitas e } \\
\text { baik karena memiliki tempat } \\
\text { duduk walaupun tempat } \\
\text { duduknya kurang nyaman, } \\
\text { perlengkapannya sangat baik } \\
\text { karena lengkap, jumlah } \\
\text { tendiknya sangat baik karena } \\
\text { lebih dari } 1, \text { sarana } \\
\text { komunikasinya baik karena } \\
\text { sarana komunikasinya dikelola } \\
\text { oleh tendik yang berpengalaman. } \\
\text { Prodi: } \\
\text { Sedangkan di Prodi Manajemen } \\
\text { fasilitas fisiknya sangat baik } \\
\text { karena memiliki tempat duduk } \\
\text { untuk menunggu yang nyaman, } \\
\text { perlengkapannya sangat baik } \\
\text { karena lengkap, jumlah } \\
\text { tendiknya hanya } 1 \text { jadi terkadang } \\
\text { terjadi antrian mahasiswa ketika } \\
\text { mengurus sesuatu. }\end{array}$ \\
\hline
\end{tabular}




\section{Tabel 2}

\section{Hasil Wawancara tentang} Keandalan

\begin{tabular}{|c|c|}
\hline Informan & Hasil wawancara \\
\hline & 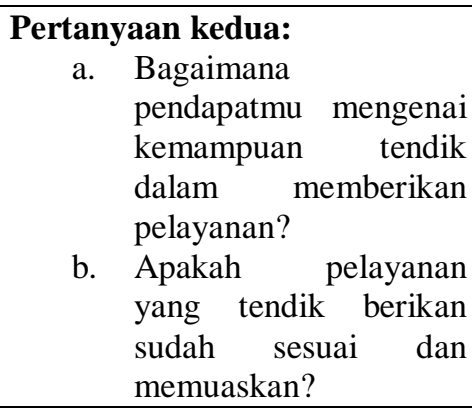 \\
\hline & Jawaban: \\
\hline $\mathbf{N}$ & $\begin{array}{l}\text { BAU: } \\
\text { Untuk BAU kurang memuaskan. } \\
\text { Karena, kadang kan, apa, ituloh } \\
\text { apa, kurang enak gituloh } \\
\text { orangnya, kurang ramah. Iya } \\
\text { kurang memuaskan, piye ya, } \\
\text { kadang kan komunikasi, kadang } \\
\text { kan suruh kesana dulu ternyata } \\
\text { dari sana BAU dulu gitu. } \\
\text { Prodi: } \\
\text { Prodi Manajemen, enak, sudah } \\
\text { baik kayaknya. Orangnya ramah } \\
\text { enak gitu untuk pelayanannya. }\end{array}$ \\
\hline $\mathbf{A}$ & $\begin{array}{l}\text { BAU: } \\
\text { Sudah cukup baik, sih. Namun } \\
\text { alangkah lebih baiknya apabila } \\
\text { karyawan yang ada di BAU } \\
\text { diperbanyak dan kantornya } \\
\text { dipisahkan setiap fakultas } \\
\text { supaya tidak terjadi lagi seperti } \\
\text { mahasiswa harus menunggu } \\
\text { lama karena antri. } \\
\text { Prodi: } \\
\text { Cukup baik, respon yang } \\
\text { diberikan petugas tidak berbelit- } \\
\text { belit dan jelas. }\end{array}$ \\
\hline IZ & $\begin{array}{l}\text { BAU: } \\
\text { Lek BAU i... yaa lumayan puas } \\
\text { tapi yo gimana, ya itu kan harus } \\
\text { antri lama bisa sampai } 1 \text { jam } \\
\text { baru dapat, kan banyak } \\
\text { mahasiswa. } \\
\text { Prodi: } \\
\text { Prodi baik, kan mahasiswa kan }\end{array}$ \\
\hline
\end{tabular}

\begin{tabular}{|c|c|}
\hline & $\begin{array}{l}\text { keperluannya nggak banyak } \\
\text { nggak kayak di BAU. }\end{array}$ \\
\hline $\mathbf{E}$ & $\begin{array}{l}\text { BAU: } \\
\text { Kalau yang di BAU menurut } \\
\text { saya itu kurang baik, karena di } \\
\text { BAU itu cuma menyediakan } 2 \\
\text { loket dan diharuskan untuk } \\
\text { melayani seluruh mahasiswa } \\
\text { kan mahasiswa dari sini juga } \\
\text { banyak. Nah, itu akibatnya kan } \\
\text { pada saat mahasiswa akan } \\
\text { melakukan validasi pembayaran } \\
\text { juga harus menunggu lama. } \\
\text { Prodi: } \\
\text { Kalau yang di Prodi menurut } \\
\text { saya sudah sangat baik. Eee... } \\
\text { lokasi Prodi sangat strategis, } \\
\text { dekat dengan tempat } \\
\text { perkuliahan, jadi memudahkan } \\
\text { mahasiswa untuk kesana. }\end{array}$ \\
\hline $\mathbf{R}$ & $\begin{array}{l}\text { BAU dan Prodi: } \\
\text { Untuk BAU dan Prodi, menurut } \\
\text { saya sudah sesuai dan } \\
\text { memuaskan karena apa yang } \\
\text { disampaikan oleh tendik } \\
\text { berkesinambungan dan sesuai } \\
\text { dengan apa yang dibutuhkan } \\
\text { oleh mahasiswa seperti itu }\end{array}$ \\
\hline
\end{tabular}

\section{Tabel 3}

Hasil Wawancara tentang Daya Tanggap

\begin{tabular}{|c|l|}
\hline Informan & \multicolumn{1}{|c|}{ Hasil wawancara } \\
\hline & $\begin{array}{l}\text { Pertanyaan ketiga: } \\
\text { Bagaimana pendapatmu mengenai } \\
\text { daya tanggap atau respon tendik } \\
\text { BAU dan Prodi Manajemen } \\
\text { dalam memberikan pelayanan? }\end{array}$ \\
\hline $\mathbf{N}$ & $\begin{array}{l}\text { Jawaban: } \\
\text { BAU: } \\
\text { Kurang tanggap. BAU respon } \\
\text { atau dalam menanggapi pelayanan } \\
\text { kurang karena kadang ada suatu } \\
\text { masalah dan ditanyakan petugas } \\
\text { BAU tidak semua merespon } \\
\text { dengan baik. Misal ada petugas A } \\
\text { yang berada di loket terus kita } \\
\text { meminta layanan tapi petugas A } \\
\text { tidak menjawab pertanyaan- } \\
\text { pertanyaan kita dan malah }\end{array}$ \\
\hline
\end{tabular}




\begin{tabular}{|c|c|}
\hline & $\begin{array}{l}\text { meminta untuk menemui petugas } \\
\text { yang lain di lain waktu. } \\
\text { Contohnya lagi kadang } \\
\text { memberikan jawaban yang tidak } \\
\text { mengenakkan. } \\
\text { Prodi: } \\
\text { Prodi responnya enak, Cuma } \\
\text { kadang agak lemot gitu aja. }\end{array}$ \\
\hline $\mathbf{A}$ & $\begin{array}{l}\text { BAU: } \\
\text { Cukup baik, petugas BAU } \\
\text { memiliki respon yang cepat pada } \\
\text { saat ada mahasiswa yang ingin } \\
\text { mengurus administrasi. } \\
\text { Prodi: } \\
\text { Sangat baik, tenaga administrasi } \\
\text { selalu sigap dalam melayani } \\
\text { kebutuhan mahasiswanya. }\end{array}$ \\
\hline IZ & $\begin{array}{l}\text { BAU: } \\
\text { Respon e yo... Iya kadang ya } \\
\text { langsung dilayani, kadang } \\
\text { nunggu, kadang kan masih } \\
\text { banyak yang diurus kan. } \\
\text { Prodi: } \\
\text { Kalau di Prodi tuh tergantung } \\
\text { yang dilayani, soalnya kan yang } \\
\text { bekerja ini orangnya hanya 1. }\end{array}$ \\
\hline $\mathbf{E}$ & $\begin{array}{l}\text { BAU: } \\
\text { Dalam memberikan pelayanan } \\
\text { menurut saya kalau di BAU itu } \\
\text { responnya sih sedikit kurang } \\
\text { tanggap ya orangnya jadi nggak } \\
\text { bisa opo sih cak cek ngunu lho. } \\
\text { Prodi: } \\
\text { Kalau di Prodi sih saya cukup } \\
\text { nyaman ya soalnya orangnya tuh } \\
\text { tanggap terus sama mahasiswa } \\
\text { tuh juga enak gitu diajak } \\
\text { ngomong. }\end{array}$ \\
\hline $\mathbf{R}$ & $\begin{array}{l}\text { BAU: } \\
\text { Tanggapan dan respon tendik } \\
\text { BAU sangat baik karena bisa } \\
\text { memberikan solusi ketika } \\
\text { mahasiswa memiliki masalah atau } \\
\text { problematika. } \\
\text { Prodi: } \\
\text { Sedangkan untuk Prodi } \\
\text { Manajemen juga sangat baik } \\
\text { karena solusi yang diberikan atau } \\
\text { respon yang diberikan sangat } \\
\text { tepat sasaran. }\end{array}$ \\
\hline
\end{tabular}

Tabel 4

Hasil Wawancara tentang Jaminan

\begin{tabular}{|c|c|}
\hline Informan & Hasil wawancara \\
\hline & $\begin{array}{l}\text { Pertanyaan keempat: } \\
\text { Bagaimana pendapatmu mengenai } \\
\text { kemampuan tendik BAU dan } \\
\text { Prodi Manajemen dalam } \\
\text { memberikan kepercayaan atau } \\
\text { kepastian mengenai informasi } \\
\text { yang diperlukan mahasiswa? }\end{array}$ \\
\hline & Jawaban: \\
\hline $\mathbf{N}$ & $\begin{array}{l}\text { BAU: } \\
\text { Kalau BAU cukup baik. } \\
\text { Alasannya... sudah sesuai, baik, } \\
\text { kalau ngasih informasi juga cukup } \\
\text { jelas, valid gitu. } \\
\text { Prodi: } \\
\text { Prodi juga udah baik, valid juga } \\
\text { ngasih pendapat, eh, ngasih } \\
\text { informasi. }\end{array}$ \\
\hline $\mathbf{A}$ & $\begin{array}{l}\text { BAU: } \\
\text { Kurang baik, sih. Terkadang } \\
\text { informasi yang diinformasikan } \\
\text { bertentangan dengan yang } \\
\text { diinformasikan Prodi. } \\
\text { Prodi: } \\
\text { Kurang baik, masih ada } \\
\text { kekurangan dalam kepastian } \\
\text { informasi yang diberikan. }\end{array}$ \\
\hline IZ & $\begin{array}{l}\text { BAU: } \\
\text { Sedikit baik terhadap informasi } \\
\text { mengenai pengumuman dari SPP, } \\
\text { yudisium, wisuda, dan lain-lain. } \\
\text { Prodi: } \\
\text { Kalau dari Prodi itu jika ada } \\
\text { mahasiswa yang ingin pindah } \\
\text { kelas atau berkaitan dengan } \\
\text { pengumuman-pengumuman yang } \\
\text { dari Rektor tersebut lalu } \\
\text { diinformasikan kepada seluruh } \\
\text { mahasiswa. }\end{array}$ \\
\hline$\overline{\mathbf{E}}$ & $\begin{array}{l}\text { BAU: } \\
\text { Kalau menurut saya di BAU itu } \\
\text { sudah sangat baik ya, memiliki } \\
\text { kredibilitas yang baik waktu } \\
\text { memberikan pelayanan kepada } \\
\text { mahasiswa, itu kalau menrut saya } \\
\text { di BAU. }\end{array}$ \\
\hline
\end{tabular}




\begin{tabular}{|c|c|}
\hline & $\begin{array}{l}\text { Prodi: } \\
\text { Kalau di Prodi Manajemen sih } \\
\text { kurang baik ya kalau menurut } \\
\text { saya soalnya tenaga } \\
\text { administrasinya kan tidak apa... } \\
\text { tidak konsisten dalam ketepatan } \\
\text { waktu jadi misal kalau mahasiswa } \\
\text { ada perlu gitu kalau misalkan } \\
\text { orangnya nggak ada harus nunggu } \\
\text { sampai berjam-jam tanpa ada } \\
\text { kejelasan waktu itu jam berapa... } \\
\text { jam berapa gitu. }\end{array}$ \\
\hline $\mathbf{R}$ & $\begin{array}{l}\text { BAU: } \\
\text { Untuk BAU menurut saya sangat } \\
\text { baik karena... kepastian mengenai } \\
\text { informasi yang diperlukan } \\
\text { mahasiswa responnya sangat } \\
\text { cepat dan juga sangat tepat } \\
\text { sehingga mahasiswa bisa segera } \\
\text { memperbaiki apabila ada } \\
\text { masalah. } \\
\text { Prodi: } \\
\text { Sedangkan di Prodi Manajemen } \\
\text { juga sangat baik karena setiap } \\
\text { permasalahan mahasiswa selalu } \\
\text { diberikan solusi. }\end{array}$ \\
\hline
\end{tabular}

Tabel 5

Hasil Wawancara tentang Empati

\begin{tabular}{|l|l|}
\hline Informan & \multicolumn{1}{|c|}{ Hasil wawancara } \\
\hline & $\begin{array}{l}\text { Pertanyaan keempat: } \\
\text { Bagaimana pendapatmu mengenai } \\
\text { kemampuan tendik BAU dan } \\
\text { Prodi Manjemen dalam } \\
\text { memberikan kepercayan atau } \\
\text { kepastian mengenai informasi } \\
\text { yang diperlukan mahasiswa? }\end{array}$ \\
\hline Jawaban: \\
\hline $\mathbf{N}$ & $\begin{array}{l}\text { BAU: } \\
\text { Kalau BAU cukup baik. } \\
\text { Alasannya... sudah sesuai, } \\
\text { baik, kalau ngasih informasi } \\
\text { juga cukup jelas, valid gitu. } \\
\text { Prodi: } \\
\text { Prodi juga udah baik, valid } \\
\text { juga ngasih pendapat, eh, } \\
\text { ngasih informasi. }\end{array}$ \\
\hline $\mathbf{A}$ & BAU: \\
\hline
\end{tabular}

\begin{tabular}{|c|c|}
\hline & $\begin{array}{l}\text { Kurang baik, sih. Terkadang } \\
\text { informasi yang diinformasikan } \\
\text { bertentangan dengan yang } \\
\text { diinformasikan Prodi. } \\
\text { Prodi: } \\
\text { Kurang baik, masih ada } \\
\text { kekurangan dalam kepastian } \\
\text { informasi yang diberikan. }\end{array}$ \\
\hline IZ & $\begin{array}{l}\text { BAU: } \\
\text { Sedikit baik terhadap } \\
\text { informasi mengenai } \\
\text { pengumuman dari SPP, } \\
\text { yudisium, wisuda, dan lain- } \\
\text { lain. } \\
\text { Prodi: } \\
\text { Kalau dari Prodi itu jika ada } \\
\text { mahasiswa yang ingin pindah } \\
\text { kelas atau berkaitan dengan } \\
\text { pengumuman-pengumuman } \\
\text { yang dari Rektor tersebut lalu } \\
\text { diinformasikan kepada seluruh } \\
\text { mahasiswa. }\end{array}$ \\
\hline $\mathbf{E}$ & $\begin{array}{l}\text { BAU: } \\
\text { Kalau menurut saya di BAU } \\
\text { itu sudah sangat baik ya, } \\
\text { memiliki kredibilitas yang baik } \\
\text { waktu memberikan pelayanan } \\
\text { kepada mahasiswa, itu kalau } \\
\text { menrut saya di BAU. } \\
\text { Prodi: } \\
\text { Kalau di Prodi Manajemen sih } \\
\text { kurang baik ya kalau menurut } \\
\text { saya soalnya tenaga } \\
\text { administrasinya kan tidak } \\
\text { apa... tidak konsisten dalam } \\
\text { ketepatan waktu jadi misal } \\
\text { kalau mahasiswa ada perlu } \\
\text { gitu kalau misalkan orangnya } \\
\text { nggak ada harus nunggu } \\
\text { sampai berjam-jam tanpa ada } \\
\text { kejelasan waktu itu jam } \\
\text { berapa... jam berapa gitu. }\end{array}$ \\
\hline $\mathbf{R}$ & $\begin{array}{lr}\text { BAU: } & \\
\text { Untuk BAU menurut saya } \\
\text { sangat baik karena... kepastian } \\
\text { mengenai informasi yang } \\
\text { diperlukan } & \text { mahasiswa } \\
\text { responnya } & \text { sangat cepat dan } \\
\end{array}$ \\
\hline
\end{tabular}




\begin{tabular}{|l|lrr|}
\hline juga sangat tepat & sehingga \\
mahasiswa bisa & segera \\
memperbaiki apabila ada & adalah. \\
masalah. & & \\
Prodi: & & \\
Sedangkan di r Prodi \\
Manajemen juga sangat baik \\
karena setiap permasalahan \\
mahasiswa selalu diberikan \\
solusi.
\end{tabular}

Persepsi mahasiswa terkait bukti
langsung terhadap kualitas pelayanan BAU dan Prodi Manajemen di UNP Kediri

Berdasarkan hasil wawancara pada tabel 1 dapat diketahui bahwa bukti langsung terkait fasilitas fisik BAU di UNP Kediri adalah kurang memadai dan masih perlu penambahan beberapa fasilitas fisik yang ada di BAU. Seringkali mahasiswa merasa tidak nyaman dalam melakukan proses validasi pembayaran dikarenakan harus mengantri bahkan sampai berjam-jam sehingga mahasiswa merasa kelelahan dan membutuhkan tempat istirahat namun saat ini ruang tunggu yang disediakan BAU kurang memadai. Dalam kaitannya dengan permasalahan ini, penyediaan sarana prasarana pendukung sangat dibutuhkan untuk pemenuhan keinginan mahasiswa demi menunjang kesuksesan pada proses pembayaran di BAU. Selain itu, BAU dan Prodi Manajemen sepertinya juga perlu melakukan penambahan jumlah tendik dikarenakan mahasiswa Universitas Nusantara PGRI Kediri setiap tahunnya semakin bertambah dan untuk menanggulangi antrian yang panjang dan lama pada saat proses validasi pembayaran maka menambah jumlah tendik yang bekerja di BAU dan Prodi maka akan semakin cepat dalam pelayanan jasa atau administrasi dan tidak akan ada mahasiswa yang mengeluh karena antrian lama. Sedangkan untuk Prodi Manajemen memiliki fasilitas fisik yang cukup memadai, namun ada beberapa mahasiswa yang mengeluh terkait dengan fasilitas ruang tunggu yang berada di ruang Prodi Manajemen perlu mendapat perhatian yang lebih. Dikarenakan tidak sedikit mahasiswa yang membutuhkan waktu yang lama terkait bertanya permasalahan perkuliahan mereka dengan pihak Prodi. Untuk itu penambahan ruang tunggu yang berada di dalam Prodi perlu direalisasikan agar mahasiswa nyaman dalam menerima pelayanan. Dari segi perlengkapan, Prodi Manajemen memiliki perlengkapan yang cukup memadai sehingga sangat baik dalam menunjang aktivitas perkuliahan.

Dari beberapa masalah yang ada diatas maka dapat dikonsepkan bahwa Sebuah pelayanan dapat dikatakan berhasil dengan baik atau sukses, apabila didukung dengan sarana 
prasarana yang memadai sebagai bukti langsung penyedia jasa kepada mahasiswa selaku pengguna jasa. Adapun Bukti langsung merupakan bukti nyata dari kepedulian dan perhatian yang diberikan BAU atau Program studi manajemen sebagai penyedia jasa kepada mahasiswa. Pentingnya bukti langsung akan menumbuhkan citra penyedia jasa dan mengevaluasi kualitas jasa. Organisasi yang tidak memperhatikan kualitas fisiknya akan menumbuhkan kebingungan atau bahkan merusak citra kampus. Komponenkomponen dari dimensi ini meliputi fasilitas fisik seperti kenyamanan ruangan, tempat parkir, kebersihan, kerapihan, perlengkapan, dan penampilan tendik.

\section{Persepsi mahasiswa terkait keandalan terhadap kualitas pelayanan BAU dan Prodi Manajemen di UNP Kediri}

Keandalan adalah kemampuan memberikan layanan yang dijanjikan dengan segera, akurat, dan memuaskan (Tjiptono, 2012). Pentingnya dimensi ini jika sampai lalai tidak diterapkan adalah kepuasan mahasiswa akan menurun karena jasa yang diberikan tidak sesuai dengan yang dijanjikan. Komponen-komponen dari dimensi keandalan yaitu kemampuan organisasi dalam menyampaikan jasa secara tepat dan penanganan administrasi secara cepat.

Dari segi pemahaman mengenai keandalan BAU dalam melayani mahasiswa dipersepsikan kurang memuaskan, dikarenakan beberapa mahasiswa bepersepsi bahwa komunikasi yang terjalin antara BAU dan mahasiswa kurang efektif. Beberapa mahasiswa mengeluh terkadang informasi yang diberikan BAU tidak sinkron dengan yang disampaikan oleh Prodi. Hal ini membuat mahasiswa merasa kebingungan dengan apa yang disampaikan. Sama halnya jika dilihat dari kecepatan pelayanan beberapa mahasiswa berpendapat kurang memuaskan, hal ini terlihat dari antrian mahasiswa yang banyak pada saat validasi pembayaran. Berbeda halnya dengan Prodi Manajemen yang memberikan pelayanan kepada mahasiswa dengan cukup cepat dan memuaskan, ditambah dengan lokasi dari Prodi Manajemen yang cukup strategis dan dekat dengan tempat perkuliahan sehingga memudahkan mahasiswa manajemen dalam melakukan proses pelayanan.

Persepsi mahasiswa terkait daya tanggap terhadap kualitas pelayanan BAU dan Prodi Manajemen di UNP Kediri

Daya tanggap dapat menumbuhkan persepsi yang positif terhadap kualitas jasa 
yang dibutuhkan. Dimensi ini terdiri dari kesigapan tendik dalam melayani penerima jasa, kecepatan tendik dalam melayani penerima jasa, dan penanganan keluhan penerima jasa. Daya tanggap adalah keinginan dan kesediaan para karyawan dalam membantu para pelanggan dengan memberikan pelayanan dengan tanggap (Tjiptono, 2012).

Berdasarkan hasil wawancara atas pertanyaan mengenai daya tanggap atau respon tendik BAU dalam memberikan pelayanan adalah beberapa mahasiswa menilai tendik BAU sangat baik dalam merespon keperluan mahasiswa, namun beberapa mahasiswa juga berpendapat bahwa tidak semua tendik BAU merespon keperluan mereka dengan baik dan terkadang terjadi kesalahpahaman dalam penyampaian informasi. Hal ini berbeda dengan persepsi semua mahasiswa yang diwawancarai terkait daya tanggap atau respon yang diberikan tendik pada Prodi Manajemen, walaupun Prodi Manajemen memiliki keterbatasan tendik, namun daya tanggap yang diberikan menurut mahasiswa sudah sangat baik dan sudah sesuai dengan yang diharapkan mahasiswa.

\section{Persepsi mahasiswa terkait jaminan terhadap kualitas pelayanan BAU dan Prodi Manajemen di UNP Kediri}

Berdasarkan hasil wawancara yang diperoleh mengenai jaminan BAU dan Prodi Manajemen dalam memberikan jasa kepada penerima jasa maka dapat diinterpretasikan bahwa BAU Dalam memberikan jaminan informasi terkait permasalahan administrasi bagi beberapa mahasiswa adalah jelas maksudnya tendik langsung menuju ke titik permasalahan yang dihadapi mahasiswa dan penyampaiannya terkesan mudah dipahami dan tidak berbelit-belit. Kredibilitas yang tinggi terlihat dari cara mereka dalam menyampaikan informasi yang diberikan tepat dan to the point. Namun, ada juga beberapa mahasiswa yang mengalami permasalahan perkuliahan yang cukup rumit berasumsi bahwa informasi yang diberikan BAU terkadang tidak sesuai dengan masalah yang mereka alami saat ini atau masih terkesan membingungkan dikarenakan kesalahpahaman informasi antara pihak Prodi dan BAU.

Untuk Prodi beberapa mahasiswa berpendapat bahwa penyampaian informasi terkait masalah perkuliahan kepada mahasiswa adalah baik dan dapat dipertanggungjawabkan kepastian 
informasinya. Hal ini bisa disimpulkan bahwa Prodi memberikan jaminan kepercayaan kepada penerima jasa yaitu mahasiswa.

Jaminan mencakup pengetahuan, kompetensi, dan sifat dapat dipercaya dari para karyawan, bebas dalam bahaya fisik atau keragu-raguan (Tjiptono, 2012). Dimensi ini sangat penting karena melibatkan persepsi mahasiswa terhadap resiko ketidakpastian yang tinggi terhadap kemampuan BAU maupun Prodi Manajemen sebagai penyedia jasa.

Adapun komponen dari jaminan terdiri dari kompetensi karyawan yang meliputi keterampilan, pengetahuan yang dimiliki karyawan untuk melakukan pelayanan, dan kredibilitas organisasi yang meliputi hal-hal yang berhubungan dengan kepercayaan mahasiswa kepada BAU maupun Prodi Manajemen, seperti reputasi kampus, prestasi dan lain-lain. Selain itu, pihak tendik BAU dan Prodi Manajemen harus bersikap ramah kepada seluruh mahasiswa yang datang. Dalam hal ini, perilaku tendik harus membuat mahasiswa puas dan merasa BAU dan Prodi Manajemen dapat menjamin jasa pelayanan yang dibutuhkan mahasiswa. Kemampuan organisasi yang dimaksud dengan memiliki pengetahuan, kesopanan, dan jaminan seperti dapat memberikan rasa kepercayaan yang tinggi dan memberikan infromasi yang pasti kepada mahasiswa.

\section{Persepsi mahasiswa terkait empati terhadap kualitas pelayanan BAU dan Prodi Manajemen di UNP Kediri}

Menurut Parasuraman (dalam (Lupiyoadi, 2013), empati merupakan kemampuan perusahaan memberikan perhatian yang tulus secara individual kepada para pelanggan dengan harapan dapat mengetahui segala keinginan dan kebutuhan konsumen dan menarik minat pelanggan untuk menggunakan jasa pelayanan yang telah diberikan serta mendengarkan keluhan atau keinginan yang spesifik mengenai pelayanan yang diberikan. Berdasarkan hasil wawancara terkait pertanyaan mengenai kemampuan tendik dalam menjalin komunikasi dengan mahasiswa adalah dari segi kemampuan tendik dalam memahami kebutuhan mahasiswa, BAU dan Prodi Manajemen menjalin komunikasi yang baik kepada mahasiswa. Tendik selalu mendahulukan kepentingan mahasiswa dan selalu memberikan solusi yang tepat kepada mahasiswa, selain itu tendik juga dinilai ramah dan sopan dalam menyampaikan 
informasi dan tidak membeda-bedakan antara mahasiswa.

Adapun Komponen dari dimensi empati adalah kemudahan dalam memanfaatkan jasa yang diberikan oleh penyedia jasa. Komunikasi merupakan kemampuan untuk menyampaikan informasi kepada konsumen serta memperoleh masukan dari konsumen dan pemahaman merupakan usaha untuk mengetahui dan memahami kebutuhan dan keinginan konsumen.

Dalam menyampaikan informasi menurut beberapa mahasiswa tendik memiliki empati yang baik dalam memahami kebutuhan mahasiswa. Selain peka terhadap kebutuhan mahasiswa, tendik juga tidak segan untuk memberikan solusi kepada setiap permasalahan mahasiswa didalam akademik maupun diluar kepentingan akademik. Keramahan dan tidak membedakan mahasiswa satu dengan lainnya dalam proses pelayanan membuat mahasiswa nyaman dalam menyampaikan aspirasi mereka. Hal ini dapat di simpulkan bahwa BAU dan Prodi Manajemen memenuhi komponen yang ada dalam dimensi empati.

\section{Simpulan}

Berdasarkan hasil dan pembahasan dapat disimpulkan bahwa persepsi mahasiswa terhadap kualitas pelayanan tenaga kependidikan BAU dan Prodi Manajemen UNP Kediri berdasarkan dimensi kualitas pelayanan bukti langsung yang meliputi fasilitas fisik masih ada kekurangan, untuk itu diperlukan perbaikan kearah yang lebih baik sesuai dengan keinginan mahasiswa. Sedangkan untuk SDM diperlukan adanya penambahan jumlah tendik guna mengefektifkan waktu pelayanan.

Terkait dimensi keandalan yang meliputi kemampuan memberikan layanan yang dijanjikan dengan segera, akurat, dan memuaskan pada Prodi Manajemen memiliki keandalan yang cepat daripada BAU, dikarenakan pelayanan yang dilakukan oleh Prodi memiliki lingkup yang lebih kecil daripada BAU. Untuk dimensi daya tanggap meliputi kemampuan karyawan dalam memberikan pelayanan dengan cepat tanggap. Dalam hal ini, daya tanggap atau respon yang diberikan tendik Prodi Manajemen dipersepsikan baik oleh mahasiswa. Sedangkan pada BAU dipersepsikan kurang baik oleh beberapa mahasiswa karena tidak semua tendik BAU 
merespon keperluan mereka dengan baik dan terkadang terjadi kesalahpahaman dalam penyampaian informasi.

Dimensi jaminan meliputi kemampuan tendik memberikan kepercayaan atau kepastian pada mahasiswa atas bahaya, resiko, dan keraguan. Kaitannya dengan jaminan, BAU dan Prodi Manajemen memberikan jaminan kepercayaan kepada mahasiswa selaku penerima jasa dengan baik dan akurat dan untuk dimensi empati meliputi kemampuan tendik dalam memahami, peduli, memberikan kemudahan, dan menjalin komunikasi baik dengan mahasiswa. BAU dan Prodi Manajemen telah menjalin komunikasi yang baik kepada mahasiswa terkait keramahan, kesopanan, dan tidak membeda-bedakan mahasiswa 1 dengan yang lain.

Implikasi dari hasil penelitian ini menunjukkan pentingnya peningkatan kualitas pelayanan di UNP Kediri khususnya pada BAU dan Prodi Manajemen guna memenuhi persepsi mahasiswa dan memperbaiki aspek-aspek yang dianggap lalai oleh pihak kampus guna meningkatkan citra UNP Kediri baik di lingkup kampus maupun di luar kampus.
Untuk penelitian selanjutnya disarankan agar kualitas pelayanan yang selama ini diberikan BAU untuk mahasiswa saat ini perlu ditingkatkan lagi untuk memberikan kepuasan kepada mahasiswa. Terutama dari segi peningkatan fasilitas fisik yang meliputi ruang tunggu mahasiswa maupun jumlah Tendik yang memerlukan penambahan. Untuk meningkatkan kualitas pelayanan pada Prodi Manajemen, maka penting bagi pihak kampus dalam melakukan pengembangan yang terkait masalah sumber daya manusia, pihak kampus perlu melakukan penambahan jumlah tenaga administrasi agar mahasiswa dapat menyelesaikan keperluannya dengan cepat.

Adapun saran yang perlu diperhatikan bagi peneliti selanjutnya yang tertarik meneliti tentang persepsi mahasiswa dan kualitas pelayanan adalah peneliti selanjutnya diharapkan untuk mengkaji lebih banyak sumber maupun referensi yang terkait dengan persepsi mahasiswa maupun kualitas pelayanan agar hasil penelitiannya dapat lebih baik dan lebih lengkap lagi. Akan tetapi layaknya penelitian yang lain, penelitian ini memiliki keterbatasan waktu penelitian dan kurangnya narasumber dikarenakan pandemi Covid-19 sehingga 
variasi tanggapan yang seharusnya lebih

beragam menjadi semakin terbatas.

\section{E. Daftar Pustaka}

Jalaludin, R. (2012). Psikologi Komunikasi. Bandung: PT Remaja Rosdakarya.

Kanca, I. N. (2015). Tingkat Kepuasan Mahasiswa Terhadap Kualitas Layanan Akademik Jurusan Penjaskesrek.

Kotler, Phillip, \& Keller, K. L. (2016). Marketing Management (16th ed.). New Jersey: Pearson.

Lupiyoadi, R. (2013). Manajemen Pemasaran Jasa Berbasis Kompetensi (Edisi 3). Jakarta: Salemba Empat.

Meilina, R. (2017). Pelayanan Publik dalam Perspektif MSDM. Kediri: Fakultas Ekonomi Universitas Nusantara PGRI Kediri.

Moleong, L. J. (2017). Metode Penelitian Kualitatif (Cetakan Ke). Bandung: PT Remaja Rosdakarya Offset.
Niara, J., Saputra, T., Sufi, W., Utami, B. C., \& Kuning, U. L. (2018). Pengaruh persepsi mahasiswa terhadap kualitas pelayanan pegawai dibagian administrasi fakultas ilmu administrasi universitas lancang kuning. 11(1), 616.

Rahayu, A. P., Lubis, H. L., \& Lubis, H. M. F. (2017). Persepsi Mahasiswa Jurusan PAI Terhadap Tingkat Pelayanan Administrasi Akademis di Universitas Dharmawangsa Medan Tahun 20162017. II(02), 138-161.

Sunaryo. (2011). Psikologi untuk Keperawatan. Jakarta: EGC Penerbit Buku Kedokteran.

Tjiptono, F. (2012). Service Management Mewujudkan Layanan Prima. Yogyakarta: Andi Offset.

Wibisana, G. W. (2017). Hubungan Kualitas Pelayanan Akademik Dengan Tingkat Kepuasan Mahasiswa Keperawatan STIKES Jenderal A.Yani Yogyakarta. 